\title{
The Transformation of an Urban Economic Area in
} Hunan Province

From state enterprise to a specialised market

\section{Gilles Guiheux}

\section{(2) OpenEdition}

\section{Journals}

Édition électronique

URL : http://journals.openedition.org/chinaperspectives/645

DOI : 10.4000/chinaperspectives. 645

ISSN : 1996-4617

\section{Éditeur}

Centre d'étude français sur la Chine contemporaine

Édition imprimée

Date de publication : 1 octobre 2003

ISSN : 2070-3449

\section{Référence électronique}

Gilles Guiheux, «The Transformation of an Urban Economic Area in Hunan Province », China

Perspectives [En ligne], 49 | september-october 2003, mis en ligne le 17 janvier 2007, consulté le 28 octobre 2019. URL : http://journals.openedition.org/chinaperspectives/645 ; DOI : 10.4000/

chinaperspectives. 645

Ce document a été généré automatiquement le 28 octobre 2019

(C) All rights reserved 


\title{
The Transformation of an Urban Economic Area in Hunan Province
}

From state enterprise to a specialised market

\author{
Gilles Guiheux
}

\section{NOTE DE L'ÉDITEUR}

Translated from the French original by Michael Black

1 One of the most distinctive features of the economic changes in China over the last decade was the expansion of the private sector. Whereas the economic expansion of the 1980s was largely due to the rural collective enterprises, expansion in the 1990s was based in part on the rapid growth of the private enterprises ${ }^{1}$. In order to understand the conditions under which private economic activity has re-emerged, identify the modalities of a shift from planning to markets, and to describe this new market economy, it is not sufficient to settle for an analysis on a scale of a single province, of one sector of activity, or of the economic policies applied. A reconstitution of the strategies of the actors, of their stories, and of the choices they have made is essential. An understanding of the economic mechanisms now appearing is conditional on their being applied to the rationales of the individual and of the family according to local configurations.

2 This was the perspective we adopted in a study that we carried out in the city of Yiyang, 75 kilometres west of Changsha, Hunan province, in the autumn of $2002^{2}$. Several hours of interviews were conducted with the owners of private enterprises and with local cadres. More precisely, the analysis concerned the limited area of a neighbourhood, which we here call an economic area. Up to the beginning of the 1990s, this comprised the places of residence and work of the employees of three state enterprises. These have since closed down completely, but their former employees are still resident, and a number of them have opened private workshops-which are also engaged in production-in the very places where formerly they had been employees. 
Thus we focused on the conversion of a space in the planned economy into a space in the market economy, and, thereby, on the conditions of the emergence of a specialised market (tese shichang or zhuanye shichang) ${ }^{3}$. The aim of this article is to analyse the forms and the underlying resources which made it possible to move from one production system to another, from a network of state enterprises to an economy of private enterprises, on the scale of a neighbourhood in the city of Yiyang.

3 The specialisation of rural or urban areas in the production or marketing of one type of product is one of the forms of the "return of the merchant" in China. Marc Blecher and Vivienne Shue ${ }^{5}$, for example, have scrutinised a market in Hebei province, which sells articles made of leather and fur. In the same province, Shen Yuan and Liu Shiding ${ }^{6}$ are researching a centre for the production and marketing of leather goods. Sun Liping and Ma Mingjie ${ }^{7}$ describe how a canton in Shandong province specialises in the cultivation of melons. These research projects are partly a continuation of those carried out by Jonathan Unger and Anita Chan, which highlight "developmentalist" local states" Tending to differ from the hypothesis that Chinese local administration is necessarily predatory or clientelist, this research shows that in places such as Baigou and Xinji, the government acts as a genuine promoter of local economic activity, and thus of an entrepreneurial bourgeoisie. The objective is to identify the new relations being established between society and the state.

4 The market which was analysed in Yiyang has at least three distinctive features. Firstly, its state of development places it "upstream" from the markets mentioned above. It has existed for only a few years and remains fragile, and comprises only a few hundred workshops, while those in Xinji and Baigou have several thousand. It is thus an especially valuable place to study the processes of emergence-rather than of development-of this new institutional form which is the "specialised market", a place of both production and marketing. Moreover, Hunan province constitutes a specific field to the extent that the development of the private economy there is recent ${ }^{9}$. Yiyang is far from the coast and the most mature markets (Guangdong, the lower Yangtze valley and Peking $)^{10}$. Finally, while the studies mentioned above were of rural China, here it is a question of an urban market, of a new production system born of the ruins of the bankrupt public enterprises.

From the decline of the state enterprises to the vitality of the market

5 At the end of 1986, the textile industry in Yiyang comprised 19 enterprises, which employed 12,785 people and produced more then twenty different products ${ }^{11}$. Textiles production alone, with four enterprises, represented over half the total capital invested in the sector, and employed nearly 4,000 people ${ }^{12}$. Three of the four state enterprises manufacturing textiles products in Yiyang were situated in the same area, in the neighbourhood of Heshan. They were Daren wachang, which made socks and stockings, Zhenzhi chang, an underwear subsidiary of the previous company, and Jingwei bianchang, a subsidiary of the latter, which made woven fabrics. Inside an area defined by a few streets and covering more than five hectares, were the three manufacturing plants-walled compounds containing many different buildings and tree-lined lanesand the red-brick residential buildings where the workers lived. In the 1970s this was one of the most prosperous neighbourhoods in the city. Fifteen years later, the state textiles industry was decimated, the enterprises closed down, the workers laid off and the buildings, both industrial and residential, in bad repair.

The end of the state textiles industry 
6 These three companies were indeed in serious difficulty during the 1990s. Daren went out of production in 1989-90. The last to close down was Jingwei, most of whose production is exported. It did not recover from the post-1997 Asian recession and from the competition from cheaper products made in South-East Asia. In fact, by 2002, the state textiles industry in Yiyang had all but disappeared. Only a conglomerate survived, with the active support of the public banks, whose leading enterprise manufactures linen fabrics, a traditional product in Yiyang, the raw material being cultivated in the surrounding countryside. For all that, the production of textiles did not cease, because individual entrepreneurs took over from the public state enterprises.

7 After a series of bankruptcies, the xiagang workers found themselves without any income, for no unemployment benefit was paid to them ${ }^{13}$. Within a few years one of the factories-Jingwei-situated in the centre of the neighbourhood, has been transformed into a market, bringing together independent workshop-stalls set up by the xiagang, while the two other factories have opened their premises to larger-scale private enterprises.

8 In 1998, there were about thirty workshop-stalls inside the walls of the Jingwei factory. In 1999, 60 new ones were created ${ }^{14}$. In the autumn of 2002, there were nearly 300 workshop-stalls inside the perimeters of the three former state enterprises, of which 155 were set up inside the walls of the Jingwei factory alone. Most of them, about 200, sell textile articles ${ }^{15}$. This specialised market provides jobs for 2,000 people, most of them former employees of the three state enterprises, who have become xiagang.

9 As well as the workshop-stalls which each employ ten people at the most, around thirty larger-scale enterprises, with dozens of employees, have moved into the same space. Former state enterprise management personnel have set up most of them. Among them there are three enterprises making socks, all founded by former Daren employees. These private companies employ about 1,000 people. There were thus a total of 3,000 people working at the site in the autumn of 2002, and one can therefore estimate that most of the former workers at the three state enterprises have found work, bearing in mind that part of the workforce was close to retirement.

10 In 2002, industrial production on the site as a whole amounted to over 100 million yuan $^{16}$. If we add the turnover of the workshop-stalls, the figure rises to over 150 million. The products manufactured are sold not only in the province of Hunan, but also in Yunnan, Guizhou, Sichuan, Shaanxi, Jiangxi, Hubei, Henan, Inner Mongolia and Xinjiang. Some of the enterprises inside the perimeters of the three state factories export to Hong Kong, Europe, the United States and even South Africa. Thus, in the space of about ten years there has been a transition from three state enterprises with several hundred employees each, to a multitude of small workshop-stalls which produce within a family framework, as well as several dozen larger private enterprises.

11 The resurgence of economic activity, under new institutional forms, has changed the neighbourhood's appearance. Restaurants have mushroomed on the main street, ranging from small stalls no more than single rooms open to the street selling food at mealtimes, to more sophisticated establishments, with enclosed dining-rooms and private rooms with air-conditioning. The former serve meals to the most modest workers and bosses; and in the latter directors and clients meet for business lunches and dinners. This street, which runs from the entrance of the factory-market to one of Yiyang's main arteries leading to the road to Changsha ${ }^{17}$, is now constantly congested. 
Stallholders, two-wheeled vehicles, delivery vans and private cars struggle to occupy the space.

The reconversion of the actors

12 In the economic space considered here, it was all the actors in the planned economy who adapted to the bankruptcy of the state enterprises and to the new conditions of the market economy. The former employees of the state enterprises have become small entrepreneurs. They rent basically equipped premises in the buildings of their former factories. Yearly rents for workshop-stalls range from 4,000 to 10,000 yuan $^{18}$, depending on their situation inside the market (certain alleys are more frequented by customers than others), and their size (from a few square metres to several dozen). In most cases, they have four or five people working in them, and sometimes more than ten. Some stalls only sell items, with manufacturing being carried out elsewhere, but in most cases manufacturing and sales take place on the same premises. Sales take place in front-the goods are exhibited on stands in view of the customers-while cutting, at a big table, and the making up of items, on one or several sewing machines, take place in the rear.

In the case of the businesses located outside the perimeter of the former factory, in the surrounding streets, these workshop-stalls are also dwellings. Mr and Mrs Zhang, whose enterprise manufactures sweaters and other woollen items, began their business in 1991. At the time, they rented 20 square metres of space which was both workshop and dwelling, shared by four people: themselves, Mrs Zhang's mother, and their twoyear-old son. There were thus three generations living under the same roof, in one room, which was the family home, the workshop with its machines, and the shop where the customers came to choose their articles. Today Mr and Mrs Zhang rent several rooms and the living space is separate from the manufacturing; one room is used as the showroom, another serves as an office where the enterprise accounts are kept.

The larger companies within the premises of the former enterprises of course pay the highest rents. As an example, one of the three private sock companies, which employs about a hundred workers, pays to the enterprise of which it occupies a part of the space, an annual rent of 50,000 yuan, which is high considering that the premises it occupies remained empty for over six years. Since 2000, the renting out of space to workshop-stalls and to the small and medium-size enterprises has brought in over 50 million yuan to the former state enterprises which no longer exist as production units, but remain the owners of the buildings and therefore receive the rent ${ }^{19}$. These revenues make it possible in particular for the three state enterprises to continue paying the pensions of their former employees ${ }^{20}$.

This conversion of state enterprises from manufacturing to property ownership is not peculiar to the area under analysis. Everywhere in China, enterprises have sought to profit from the value of the sites they occupy. In the centres of the prosperous coastal cities, they have been sold to the highest bidders, new economic activities have been developed on them, or they have become residential property developers themselves ${ }^{21}$. But property values in Yiyang ruled out this kind of development. What is noteworthy here is that the area under analysis is reconverting with the same actors and in the same economic sector.

Indeed, it is not only the former workers (or company managers) who have become self-employed, but also the former factory heads whose professional activity has been radically transformed. Mr Wang was appointed head of the Jingwei factory when 
production had already ceased. He is still in the same job (changzhang) since the enterprise has not ceased to exist administratively. But a new administrative entity was created in 2001, the "specialised market in textile articles of Yiyang" (Yiyangshi zhenzhipin zhuanye shichang) of which he simultaneously became the director (zongjingli).

Mr Wang, who is also secretary of the Communist Party, also adapted to the new environment by carrying out a veritable ideological conversion to the market economy. In a document addressed to the municipal government of Yiyang, Mr Wang preached the virtues of the market economy as the basis for the industrialisation and urbanisation of the city: "The basis of industrialisation is the market (...) It is only by satisfying demand as expressed in the market that industrialisation can follow the right path and be successful. If one moves away from the market, industrial production becomes like a tree without roots or a river with no source. The basis of industrialisation is the market." 22

Share of the two main sectors of activity in the total industrial production of Yiyang (in \%)

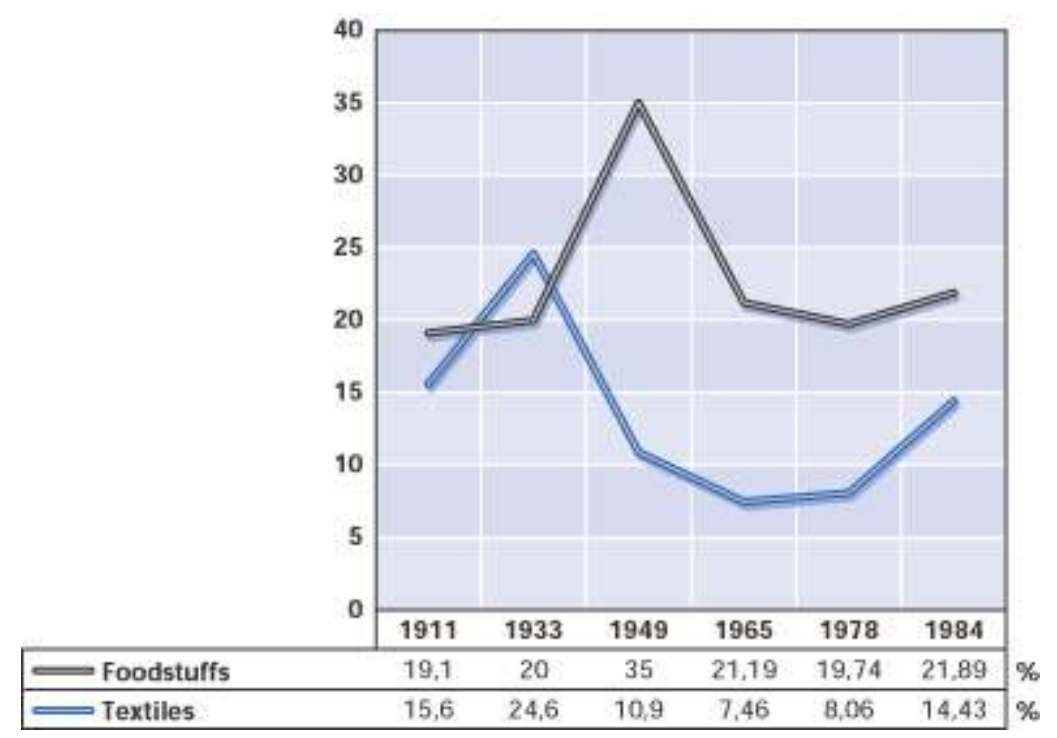

Source: Yiyang ditu zhi, Beijing, Xinhua chubanshe, Beijing, 1997, pp. 1089 and 1090.

What appears to be the ideological conversion of an administrative and political leader is also a pragmatic conversion to reality. It is his career in the municipal authorities that Mr Wang is laying on the line by supporting the interests of the community of independent businessmen. By allowing the xiagang to engage in new revenueproducing activities, he is solving a problem for which he is deemed responsible. A central government directive stipulates that "a factory director whose xiagang have not settled the question of how to feed and clothe themselves, and do not have enough to live on, cannot earn more than 500 yuan a month"23. The market's success may make it possible for him later to rise in the ranks of municipal administration or of the Party. Thus both the former employees of the state enterprises and the managers appointed by the administration are both gambling their survival on the birth of the specialised market in textile articles.

It is thus all the actors present on the site who have reconverted: the "lifetime" employees of the state enterprises have set up in business, the former factories have 
become property owners providing premises, while the directors of these establishments have become the project managers of private commercial activity. In order to explain this rebirth of production in the framework of new institutional forms (from the state enterprises to the private ones), we must look at the economic history of the city of Yiyang.

A long industrial history

The textile industry in Yiyang has a long history. By 1840 the city had family workshops in which fabric was produced. Although after the Opium Wars, competition from imported products damaged local activity, the existence of textile crafts is attested by a local chronicle published under the reign of the Emperor Tongzhi (1862-1874) ${ }^{24}$. All through the twentieth century, the textile industry ranked second among the most important industrial activities of the city (see table).

"Western socks" and other textile articles

21 The sock and underwear industries date from the beginning of the republican period. In 1919, Mrs Li Yuzhen studied in Hankou, now Wuhan, the technique of sock weaving, and on her return to Yiyang, bought a machine-a manually operated spinning frameand this was the origin of the Zhenji sock workshop, and of the industry in Yiyang. The following year, a Lutheran pastor, Yan Youwen, imported eight machines and set up the Daren company. At the time, knitted fabric was a new kind of production, and the products were called "Western socks" (yangwa) ${ }^{25}$. The market developed quickly and was very profitable. In 1924 Daren became a limited liability joint stock company (Daren gufen youxian gongsi) with a registered capital of 50,000 yuan. The factory also made towels and other textile articles. In 1923, Daren bought Japanese machines in Shanghai and began to manufacture jackets and waistcoats. In 1925, Zhenji also began to make clothes in corduroy and flannel. In May 1925, Daren invested 7,000 yuan in the construction of a new building. At the time it was the first factory in the province of Hunan to use electric machines to knit socks ${ }^{26}$.

In the 1930s, the Daren Company had a capital of 100,000 yuan, or $11.4 \%$ of the total capital invested in the industry in Hunan province, and annual production was $1,080,000$ pairs of socks. Recognition of the brand grew thanks to participation in national commercial exhibitions, in particular in Peking in 1929 and 1935 where "Daren" socks won prizes ${ }^{27}$. In 1929, the woven underwear manufactured by Daren won the second prize at the national commercial exhibition. In the 1930s, the Daren and Zhenji brands accounted for more than half the province's textile clothing production. In 1936 there were 28 textile companies which employed 2,116 people. Textiles were the main activity. Daren, the biggest textile enterprise in the province, employed 554 people. It was then the biggest textile enterprise in Hunan province. In 1937, Yiyang had 17 enterprises making textiles with over 1,500 machines, an activity which employed 750 people $^{28}$.

The industry suffered during the Sino-Japanese war; activity declined and at the end of 1948, there were only nine textile enterprises in Yiyang. In 1948, the Zhenji factory went bankrupt. In 1949, total sock production (Daren and five other smaller enterprises) in Yiyang was 278,000 pairs. In 1950 the management of the Daren enterprise became a public-private collaboration (gongsi heying). The same year, the local government invested 70,000 yuan to modernise the equipment. In 1952, the enterprise changed names (Daren mianzhi chang) and became a state enterprise. In 1956, Daren built new buildings and production was modernised with 66 electric 
machines. During the Cultural Revolution, the enterprise changed names again. It became Yiyang shi dongfang hong wachang-Red East Sock Factory of the City of Yiyang. The enterprise went back to its original name of Daren in $1980^{29}$.

In 1965 in the course of product diversification, Daren opened a new company to make undergarments, Yiyang Zhenzhichang, where it set up part of its plant and of its employees. In 1973, the factory exported to the United States for the first time. In 1981, Zhenzhichang in turn opened a subsidiary, Jingwei, which began with production of knitted woollen garments and quickly moved to the production of undergarments.

Thus it is in Yiyang that the Chinese sock industry was partly born. At first semi-craft, the activity gradually expanded and modernised over the century, a process marked in particular by the use of electricity to drive the machines. While Daren wachang has an almost hundred-year history, the undergarment industry is over fifty years old. The brands associated with the enterprises ("da" for socks and "taohua" for underwear) enjoy definite brand recognition nationally.

Family histories

The history of the textile industry is not only one of institutions-the enterprises-but also of individuals and families. Individual and family histories are intimately connected to the industry. Mrs Liu's personal history has been linked to the textile industry for two generations. Her mother, from the town of Ningxiang, a few dozen kilometres south of Yiyang, came to work in the Daren sock factory at the age of 13. She was the eldest child of a family related to the founders of the company ${ }^{30}$. Mrs Liu's mother spent all her working life at Daren; she began her career as a worker and finished as head of one of the three workshops in the factory. Mrs Liu's father, born at the beginning of the century, finished secondary school, after which, on the recommendation of an uncle, a division commander in Chiang Kai-shek's army, he began a military career. During the civil war his army corps went over to the communist camp. After the capture of Yiyang by the communists, he was appointed Secretary of the Communist Party in a textile factory in Yiyang, not Daren where his bride-to-be worked, but in another company which manufactured fabrics.

Their daughter, Mrs Liu, born in 1957, joined the Daren factory in her turn at the end of her secondary education, in 1977. She was taken on as a worker, employed to sew buttons. Like her mother, she was the eldest, and it would have been too expensive for her to study further. At the time, she earned 19 yuan a month, a significant income which she gave to her family. In 1979, she passed the examination to take university courses. While working at the factory, she began to study again, following classes on television for three years. She was then appointed to the enterprise's technology office, and was then successively in charge of personnel management and training. She finished her career as a middle manager (zhongceng ganbu) in charge of sales. Mrs Liu lost her job at Daren in 1991. This double biography suggests the extent to which, in Yiyang, family histories are closely linked to the textile industry. Mr Zhang provides another example. He began working in 1977, at 19. Like his wife, he was to work for 20 years in a textile enterprise in Yiyang, before both were laid off in 1989-90.

In seeking to understand why the xiagang have gone into business in family workshops, part of the answer lies undoubtedly in this correspondence between the individual and family histories and the industrial history of Yiyang. Biographies of individuals and families have been tied to the textile industry for one or several generations. Knowledge has been acquired-the use of the machines, product design, which all in all 
is fairly basic in the case of the manufacture of textile articles, relations with customers and suppliers-and there is a capital of resources which can be drawn on. It is no doubt because these resources are available that the xiagang have stayed in Yiyang, rather than choose another possible path, which would have been migration to a coastal city ${ }^{31}$.

One of our informants, owner of an enterprise with several dozen employees, justifies the choice he made of opening his establishment in Yiyang: not only is the available workforce-those who have been laid off-numerous (and inexpensive) but "there are also technical resources (jishu ziyuan), as well as a culture (yi zhong wenhua). There are specific advantages here. Competent workers abound".

Among these specific advantages is the reputation of the city of Yiyang as a production centre for textile articles. Yiyang has been well known for a long time (we have already mentioned the prizes obtained at commercial exhibitions in the first half of the twentieth century) for this kind of article. The brands constitute a resource in themselves. Thus one of the private enterprises set up by a former manager at Daren produces socks with the brand Guiren, which makes a specific reference to the former state enterprise Daren. Even though the new enterprises, whether family workshops or small and medium enterprises with several dozen employees, have had to find their own distribution and customer network, it is likely that the development of the specialised market is partly due to the reputation of the place.

In this respect, the continuity between the two kinds of production organisation, from the state enterprise to the family workshop, must be noted. According to the former head of a state factory: "Formerly, the management of the state enterprise was not very rigorous. Many workers took home parts from the machines, that is one of the corrupt aspects of state enterprises. Thus many workers manufactured secretly at home. When the enterprise decided to cease production, there were in the workers' living quarters already ten or so family workshops which made underwear" ${ }^{32}$. There is therefore continuity between the two production systems which overlapped chronologically. Before the state enterprise was declared bankrupt, there already existed family workshops which used raw materials and machines spirited away from the state factory ${ }^{33}$.

The transition from the status of employee to that of small entrepreneur was made all the easier for certain resources being also available to individuals. The long history of the textile industry in Yiyang, and their experience in running the machines are factors on the basis of which economic activity was restored, in the case of individual enterprises.

The municipal authorities and the specialised market

33 Although the local authorities played no part in the emergence of the specialised market, an initiative taken by the xiagang themselves, the former heads of state factories have since, as we have said, taken on responsibility for the market. That is to say that a new form of collective authority or individual intermediary between the individual enterprises and the local administrations has appeared. Spokesmen for the interests of local entrepreneurs, these institutions are at the same time the representatives of the state which appointed them. Analysis thus shows how far local authorities are from making up a homogenous whole.

An indifferent local government

The main obstacle to the establishment by the xiagang of individual business (as well as to the emergence of a private sector in general) is the initial capital ${ }^{34}$. Most of them 
financed their establishments out of their own pockets or by means of personal and private finance networks, most often providing between 10,000 and 20,000 yuan. In order to obtain the indispensable cutting or sewing machines, former factory employees have used their personal savings, or have borrowed money from relatives or friends.

“The government gives us no money, the banks don't lend to us, I am a small individual entrepreneur (getihu)", confides Mr Zhang. Another, who has created an enterprise with a hundred employees, testifies in these terms: "The money was all borrowed, from my mother, from my mother's sister and from other relatives. To start up, I borrowed 300,000 yuan, and then I borrowed another 600,000 yuan. I pay $12 \%$ interest a year. The banks don't lend. You have to have a sum deposited in an account as a guarantee. But if I had savings, why would I go and borrow? Getting a bank loan is difficult." ${ }^{35}$ The lack of access to bank credit for private entrepreneurs, particularly the smallest of them, is a well-known and frequently mentioned problem ${ }^{36}$.

If Mr Wang, head of the specialised market and also director of the factory in which it is established, is to be believed, the initiative for the development of the specialised market is strictly local and due to the xiagang. "We [the management of the Jingwei factory], we wanted to restart the factory's production. So we took two decisions. The first was to lease the machines to the employees. The second was to develop this market. We had a visit from the deputy mayor in charge of industry who considered that leasing the machines was a good way. We took the mayor to meet the xiagang who were making underwear. He suggested organising these people and installing them in a market which already existed. The mayor wanted me to organise a meeting with the xiagang. But the xiagang didn't want to leave this place which has its particularities. At that time we imagined a big market, but nothing was decided (...). When it started there wasn't a single shop. Between 1998 and today, 155 shops have opened (...). The government did not invest a single yuan in the plan (...). The money received in rent is used to set up the workshops in the factory. It did not cost us any money. In any case, we don't have any money either. So the development was gradual. It wasn't all at once that we had a big market." ${ }^{37}$

The birth of the specialised market can thus be attributed to the initiative of the xiagang in going into business in co-operation with the management of the factory who provided them with premises and rented them the machines. While a representative of the municipal government did visit the premises, his suggestion (installing the workshop-stalls in another market in the city, in a space properly designed for that activity) was rejected. Several reasons can be advanced for this refusal: the costs incurred (particularly in daily travel since here the individual entrepreneurs are close to their places of residence), the necessary proximity between places of sale, of production and of residence (often in fact one and the same), fear of seeing their influence diluted by mingling with other kinds of businesses (and a vague awareness of the advantages of forming a specific interest group). The transformation of the factory buildings into commercial spaces was in fact entirely self-financed by the factory managers, which explains the gradual character of the development, the rents of the initial occupiers making possible the fitting-out of new stalls.

The indifference of the local authorities to the fate of the xiagang, and their lack of any participation in the creation of private establishments, explains the bitter resentment they feel towards the state, taken as a whole: "Those who are in politics discuss how to 
promote private enterprises (minying qiye), but I will say something which is not pleasant to hear. All that is to deceive people. (...) I haven't anyone in the background to support me. There is no way [to obtain financing]." ${ }^{38}$

Confronted with the problem of financing his private business, this individual entrepreneur, in the name of his entire generation, passed a severe and disillusioned judgement on the communist Party and its responsibility: "We are both [he and his wife] people of Mao Zedong's generation, we thought that the Communist Party could not abandon power, that the state work units could not do otherwise than take care of us (buhui buguan women), that there would always be enough to eat. At that time we had it figured out all wrong (...). Among us, in our generation, there are many who are in difficult situations. They get no support from the government. They devoted their youth to the enterprises of the Communist Party. When we reached the age of forty they forgot about us. And when our [private] activities reached a certain level, the government's Bureau of Industry and Commerce came again to ask us for money, for management costs. I laughed at them: what do you look after? All you do is extort money from us. You don't bother about whether I have enough to eat." ${ }_{39}$

Bitterness toward the state and the Communist Party for its past behaviour, and the feeling of having been a sacrificed generation changes to anger towards the administration which imposes taxes of all sorts on private activities. For all that, it would be wrong to conclude that there is hostility between local government (and its offices, particularly of taxation) and the private entrepreneurs. At the same time as the specialised market was being formed, there appeared actors related to the local state whose ambition is to federate the energies of local entrepreneurs and to co-ordinate the activities of local administration. From this point of view, the local state seems to have means of taking on individual initiatives.

The birth of an institution for regulation and planning

41 What is to be seen in Yiyang is not a confrontation between individual entrepreneurs and the municipal government; there are intermediate institutions to connect them. First of all the management of the former state factories, who, as we have said, have remained in place with a new mission: no longer that of mobilising men to organise production within the plan, but of collecting rent from tenants to finance the development of the market; the enterprises have not disappeared but have become "property companies". But there are also new organisations in place. We have mentioned the "specialised market in textile articles". There is also a "management committee of the market in textile products" (zhenzhipin shichang guanli weiyuanhui) set up in 2001. This committee brings together the factory directors (who are still at their posts) as well as a number of representatives of local government, in particular the Bureau of Industry and Commerce (gongshang xingzheng) and the tax office (shuiwu). This bureau has a triple role: that of intermediary, co-ordination and programming.

It is an intermediary, since it has, since the beginning, collected taxes from the enterprises on behalf of the various administrations. As Mr Wang states: "In order to maintain the healthy development of this market, we set up this committee. In order to prevent each office of the administration coming and interfering in the market and levying taxes in a disorganised way (lailuan shoufei). Offices which want to make levies have to go through us, and cannot do it alone. It is us who collect the taxes and then pass on the amounts collected." ${ }^{40}$ This suggests that the committee plays a regulating role in the collections carried out by the administrations, apparently in charge of 
protecting the interests of the individual entrepreneur against their predatory behaviour. It is also a co-ordinator to the extent that it is the only interlocutor between the various administrations and the actors in the market.

In terms of programming, the committee organises a development plan. It participates (like other administrations) in the definition of a medium- and long-term development strategy. Since 2000, various government offices involved have been conducting research into the market in order to encourage its development. At the beginning of 2001, the municipal government organised a conference to discuss development projects, and the market management committee was the product of these discussions. How can the market be built and developed in future? To answer this question, the authors of the text "Enquiry and proposals on the construction of a programme and the development of the Yiyang specialised textile article market" met the management of the three closed state enterprises and the owners of the private enterprises located on their premises.

45 A number of problems were identified ${ }^{41}$. The quality of collective facilities, which all date from the time of the planned economy and which are unsuitable for the development of a market of stalls which sees large numbers of visitors, needs to improved: public toilets, refuse collection and street maintenance need to be renovated or improved. At present the environment of the market is described as "dirty, chaotic, insufficient" (zang, luan, cha). As we have said, the main street, which is too narrow and without sidewalks, which goes from the main Changsha-Yiyang road to the entrance of the market, is permanently congested, making access difficult for both goods and potential customers. Fire prevention equipment is inadequate, as is the electricity supply to the workshops, both factors linked to the transformation of premises formerly designed for mass production into a multitude of small establishments ${ }^{42}$.

"For the moment, our management of the market is not perfect. The committee has just been set up. But we will soon put in place a general plan: how to upgrade the street, how to build the workshops, all that will be done according to the rules, the projects will be submitted to the committee. It won't be like before. Someone builds. Someone else builds, but there is no overall plan. Today the stalls (tan) are dirty, but they provide a living for a lot of people, so we have to develop in a stable manner. First we have to protect (bao) ourselves, first we have to mark out a development zone (fazhan qu) here, and then develop it".

It is not only the physical infrastructure of the market which is inadequate: the same document admits that the immaterial conditions of business are also inappropriate. The report mentions the fact that most of the workshops have developed on individuals' own private funds, that it is very difficult for them to obtain the support of the banks, and that as a consequence their financial capacity is limited. Also pointed out is the lack of established brands or labels for the products produced, which also harms their development (in fact, some stalls use their own brand, as do the small and medium enterprises on the premises). In order for the products of the Yiyang textile article market to be known all over China and even abroad, a brand (pinpai) must be established, and possibly promoted on television. Therefore a brand and a symbol of the market need to be created. Also necessary is the establishment of a professional association (tongye xiehui) to bring together all the entrepreneurs. 

years, the creation of several hundred new boutiques is planned in order to bring the workforce up to over 6,000 people. Fifty factories need to be brought in and production and turnover brought up to over 500 million yuan, reaching, in a second three- to fiveyear stage, a production value of over 1 billion yuan. In the framework of this development will have to be created a raw materials supply market. Finally, the document also contemplates the development of a ready-to-wear market.

The drawing up of a development "model"

Beyond the drawing up of a development plan with concrete objectives in terms of public investment, of enterprise and job creation and of production values, there is a real model theorised by the local market leaders. Several points seem worth emphasising: the determination of the committee, its insistence on the necessity for collective action, the importance of specialisation and the reference made to the advantages specific to the area under consideration. The Party's municipal committee and the municipal government are enjoined to draw up a development policy ${ }^{44}$. "The authorities must take seriously the growth of the market which has up to now developed spontaneously. The management of the market needs to be improved. All the administrations concerned must support the development of the market, especially the Bureau of Trade and Industry and the tax authorities". The text therefore calls for supporting action from municipal government as well as from the municipal committee of the Party.

Moreover, the same document justifies a leading role for the organs related to local state government and draws up a basic theory of the mode of development which has been applied largely spontaneously. What the market economy requires, it says, is that "the government supervise the market, [that] the enterprises obey the market". "The development of the private sector, the small enterprises need leadership, it is not good for them to rely exclusively on themselves, it matters little whether it is the government or structures under the government's authority, if there is no leadership, then there is no chance of development" 45 . These formulations, which give themselves airs of development theory, are in fact means of bringing pressure to bear on local government, which has been indifferent up to now.

51 If a programming and co-ordinating role is recognised where the state-related structures are concerned, it is in particular in the face of the lack of capacity of influence of each establishment taken separately. And here we are confronted with a kind of theory of the mode of development characteristic of the specialised market areas in China: "One must conform to the slogan 'a small product, a big market, a small industry, a large number of enterprises, a high density of enterprises (xiao chengpin, da shichang, xiao qiye, da juji)"'. The expression juji here translated as "a high density of enterprises" evokes the bringing together in one space of a large number of similar and independent units. This is the heart of the development "model" under consideration. It designates a type of collective different from that characteristic of the collective economy (jiti) and suggests a voluntary association of members with common interests. This new model could be summarised as follows: favouring the development of small private establishments in a local area with specific resources.

Local leaders comment repeatedly on the specific resources of the area considered, which must translate economically into the specialisation of the market. Their argumentation takes on the appearance of a scientific theory summarised by an outline 
which suggests that the higher the degree of specialisation, the greater the development possibilities.

In our interviews great emphasis was laid on the specific characteristics of the economic area under consideration: "If a locality wants to develop the private sector of the economy (minying jingji), the most important element we call the power of the culture (wenhua diyun); development of the private sector calls for choosing an objective. Here we have made a choice, we make textile articles". The slogan printed on the advertising billboard at the entrance to market also makes an explicit reference to the industrial history of the place: "Recognise a century old tradition, make the splendour of textile live again".

In the minds of the market leaders we met, it is indeed a "model" in the sense that they deliberately draw inspiration from the experiences of development in other areas. They speak of the visits they have made to other cities in Hunan, in particular to Zhuzhou, fifty kilometres south of Changsha, to the market of Loudong-"There's a market which has managed to export its particularities (tese). It's a ready to wear market, known all over China. It's a model of success"-, or in the province of Guangdong, in particular to Humen, where there is the biggest ready-to-wear market in the whole country.

Once these local resources are identified, the development of the private sector is planned in the framework of a determined policy on the part of the local authorities, whose role it is to bring diverse energies together and in particular to finance the necessary infrastructure: "Each area has its specificities, so we have exploited ours. In order to favour the industrialisation of Yiyang, we believe that the government may make a major investment. No firm decision has yet been taken, but members of the government have mentioned it. Once the decision is taken, the government will invest in infrastructure".

In the present state of development of the city of Yiyang's textile articles market, it appears that local state government is not a homogenous whole. Its representatives within the market are now putting pressure on the local authorities to obtain investment, after years of indifference. With an acute awareness of the resources specific to the area considered, these actors are making themselves the spokesmen before local government.

57 In contrast with other markets studied by other authors in China, Yiyang's specialised textile articles market is recent and modest in scale. The first workshop-stalls were set up in the area considered at the end of the 1990s, and in the autumn of 2002, the market's leaders were trying to pressure the municipal authorities, who had until then been indifferent, into a financial commitment to the development of the market. What was observed was thus the beginning of a process which could mean an increasing involvement by the local authorities in the form of investments (in streets or buildings), as has been observed elsewhere. No doubt the involvement of the state here depends also on the profits it deems possible, since all in all developing a market is one of the less expensive ways of increasing local financial resources ${ }^{46}$. In this hypothesis, the government of Yiyang would become a "developmentalist state".

What deserves to be emphasised is that, at the origins of this market, are to be found the initiatives of the xiagang who found in private activity a means of economic survival. Laid off without any compensation, they were forced to innovate. The creation of the stalls is done without any public support; the financing is by the individual or the family. The xiagang bring together the only resources at their disposal: their skills as 
textile workers and the premises at their disposal, living and production places abandoned by the bankrupt state enterprises. As in other markets, the local state thus took no part in the creation of the market, no doubt indifferent also because of its own shortage of resources. In Baigou, Shen Yuan ${ }^{47}$ has observed a comparable process: the local authorities first reprimanded and then tolerated, before deciding to support the initiatives once they understood all the financial benefits they can derive from them. In Yiyang the process of development of a specialised production and sales area has not owed much to the local government, whose action-and this remains to be seen-may eventually come to supplement independent initiatives.

In Yiyang, those who have become the spokesmen of the workers-turned-bosses are the former factory directors who are both administrative and political leaders. Because their careers are at stake, these men, representatives of the local authorities within the markets, make themselves the defenders of the private entrepreneurs who are their tenants. One of the questions which another study will have to answer is the legitimacy of these representatives in relation to those they "administer". Apparently, they act more as defenders of the interests of the local economic area than as representatives of the local authorities who, in fact, have no development policy. Thus one should understand the emergence of "developmentalist" local authorities as the result of deals being made within the authorities themselves. The developmentalist character of a local state is the fruit of a process of construction.

60 A second conclusion seems to us essential: there is a possible continuity between the planned economy and the market economy. The example of Yiyang's specialised textile articles market is another illustration of the originality of Chinese economic reforms, far from any "shock therapy", and argues in favour of the gradual adaptation of the existing structures and institutions. The salaried workers and managers of the state enterprises have become private entrepreneurs, the state enterprises, no longer producers, have become landlords and rent collectors, while the representatives of the local authorities and of the Party within the state enterprises have become promoters to the local government of private entrepreneurs. This conversion of the actors and of the area is certainly born of necessity, for they had all lost their source of income. But it is also a consequence of the management of resources particular to the local area.

61 The initial response to the new environment came from the workforce which had been laid off. They had skills, they controlled resources, and, as we have said, some of them, even before the factory closed, had already set up in business. There were already the beginnings of individual activity. The market economy did not appear here as grafted from outside onto a derelict system; it has emerged in the framework of an endogenous adaptation by the local actors and institutions.

62 All territories have a history. In Yiyang, the specialised textile articles market, a new social form, grew within an older institution, the state enterprise, which is itself the heir of industrial establishments set up at the beginning of the twentieth century. The community of workers, some of whom have several generations of experience in the textile industry, is becoming a community of independent producers and sellers ${ }^{48}$. We therefore agree with Isabelle Thireau's assessment that, in studying China in transition, we must take into account the "institutions, customs and norms" which "support new possibilities" ${ }^{49}$.

Do we have here a possible model for the reconversion of urban areas in crisis? This reconversion would not have been possible without two major conditions which 
guarantee particularly low production costs: the lack of application of legal requirements and the choice made of family self-employment. For example the legislation dealing with the distinction between individual enterprises and private enterprises is not applied; one can make the supposition that, generally speaking, it is not the regulations which prevail, but case-by-case negotiation between the administration and private entrepreneurs.

Above all, both the employees of private enterprises and their bosses now work more hours than they did as employees of state enterprises, a situation which is likely to continue, given the number of workers without any available jobs. The key to this reconversion is therefore former employees setting up on their own but in worse working conditions, of extreme insecurity and without a guaranteed income. While they have kept their living quarters, they are now without any protection against all other dangers: illness, unemployment and retirement. The owners of small enterprises in China now find themselves in the situation of their Asian neighbours in the 1960s and $1970 \mathrm{~s}^{50}$.

Moreover, the development of this kind of market in Yiyang depends also on the character of the products manufactured. It is possible in industrial sectors where laidoff workers can easily reappropriate the technology, the skills and the market. This is particularly possible in the case of the textile industry and clothing manufacturing, and in other manufacturing industries, but this is not the case in heavy industry sectors or in high-capital industries. Moreover, although the products manufactured in Yiyang are unsophisticated, they correspond to the demand of rural populations. On the coastal edge of the country, consumers would probably be more demanding and competition keener. The case of Yiyang's specialised market is therefore only one possible way of reconversion, among others, of the urban economic areas dating from the planned economy.

While the local authorities are still barely involved in the promotion of the economic area considered, the role they will play will have to be observed. They will promote local development by investing in infrastructure but will also participate in the construction of the market as an institution. We have mentioned the building of a brand which would be used collectively, but more widely they will participate in the setting up of product norms-these are the condition for the common use of a brand and possible advertising campaigns-and the standardisation of employment conditions. The specialised market thus appears as a revealing area of observation at the local level of the state and of its agents as producers of norms and regulations in negotiation with local actors. Already, the construction of a theory of local development by the leaders appears to be a means of legitimising their role. 


\section{NOTES}

1. For a quantitative evaluation of the sector in China and commentary on the relevance of this category, see Gilles Guiheux, "The Incomplete Crystallisation of the Private Sector", China Perspectives, No. 42, July-August 2002, pp. 24-35.

2. The results presented here are those of an introductory study which will be pursued.

3. We have adopted the term "specialised market" because it is used by the local actors themselves. In fact this market brings together stalls which are places of both sales and production.

4. We have taken this expression from the collective publication directed by Isabelle Thireau («Le retour du marchand dans la Chine rurale », Etudes rurales, 161/162, Paris, éd. de l'EHESS, 2002) which we found particularly stimulating.

5. Marc Blecher and Vivienne Shue, "Into Leather: State-led Development and the Private Sector in Xinji", China Quarterly, 166, 2001, pp. 368-393.

6. Shen Yuan, « Naissance d'un marché » and Liu Shiding, «L'alliance entre un grand marché et une multitude d'ateliers domestiques ", in I. Thireau, op. cit., 2002, pp. 19-36, 37-52.

7. Sun Liping et Ma Mingjie, « Forcer le peuple à s'enrichir ! ", in I. Thireau, op. cit., 2002, pp. 165-182.

8. Jonathan Unger and Anita Chan, "Inheritors of the Boom: Private Enterprise and the Role of Local Government in a Rural South China Township", The China Journal, 42, July 1999, pp. 45-74.

9. In 1999, the province of Hunan ranked seventeenth in the number of its private enterprises (siying qiye) and fifth in the number of its individual enterprises (getihu). Zhang Houyi, Ming Zhili, Liang Zhuanyun, eds, Zhongguo siying qiye fazhan baogao $n^{\circ} 3$, 2001 (Report on the development of private enterprises in China), Peking, Shehuikexue wenxian chubanshe, 2002, pp. 22 and 36.

10. In the province of Hunan, at the time of the census in 2000, the population was $70 \%$ rural, whereas the national average was 64\% (Hunan nianjian (Hunan Annual), Peking, Zhongguo tongji chubanshe, 2002, p. 81 and China Statistical Yearbook 2002, Peking, Zhongguo tongji chubanshe, 2003, p. 95).

11. Yiyang shi zhi bianzuan weiyuanhui (Commission for the compilation of the chronicle of the city of Yiyang), Yiyang shi zhi (chronicle of the city of Yiyang), Peking, Zhongguo wenshi chubanshe, 1990, p. 221.

12. Yiyang shi zhi, p.221.

13. The former employees are now xiagang, literally "fallen" from their jobs.

Technically without jobs, they are nonetheless not considered unemployed (shiye) for they continue to be accounted for by their former enterprises. In theory they should be receiving a minimum income. But in fact, in the case at hand, the enterprises did not have the resources to pay compensation to their former employees. For an assessment of this phenomenon on the national scale, see Jean-Louis Rocca, 2000, « L'évolution de la crise du travail dans la Chine urbaine ", Etudes du Ceri, 65.

14. "Guanyu guihua jianshe he fazhan Yiyang zhenzhipin zhuanye da shichang de diaocha he jianyi » (Study and proposals for the elaboration of a programme and for the development of the specialised market in textile articles in Yiyang), internal document, municipal administration of Yiyang, October 2002, p. 2. 
15. « Guanyu guihua jianshe ... », p. 2.

16. Figures quoted in « Guanyu guihua jianshe ... », Yiyang.

17. Since 1998, Yiyang has been connected to Changsha by a 75-kilometre toll highway.

18. The salary of a worker in a private enterprise in Yiyang is 600 yuan per month.

19. Figure quoted by « Guanyu guihua jianshe ... », Yiyang.

20. If the state enterprises which have gone bankrupt do not disappear as administrative entities, it is in particular for this reason, that they are responsible for the payment of pensions of former employees.

21. Another kind of development has been the handing over of sites to a property developer in exchange for the "delivery" of a certain number of buildings or apartments, where the enterprise houses its own personnel.

22. "Shichang ladong chanye, chanye jinrong shichang, jianshe he fazhan tese shichang, tuijin Yiyang gongyehua jincheng" (Developing industry beginning with the market; industry which makes the market prosperous; building and developing a specialised market; promoting the industrialisation of Yiyang), internal document, municipal administration of Yiyang, October 2002, 14 pages.

23. Interview with Mr Wang.

24. Yiyang shizhi, p. 220.

25. "Western socks" because the equivalent in China was a strip of fabric rolled around the ankle. Westerners introduced the knitted sock.

26. Yiyang xian zhi (Chronicle of the district of Yiyang), Yiyang xianzhi pianzuan weiyuanhui, 1992, p. 243.

27. Yiyang ditu zhi, p. 115.

28. Yiyang shi zhi, pp. 220-221

29. Yiyang ditu zhi, p. 115.

30. This relationship was sufficiently indirect for Mrs Liu not to be able to remember it precisely (Interview).

31. Migration to a coastal city probably presents more dangers than the assurance of a better financial situation.

32. Interview.

33. On the subject of the widespread theft in state enterprises, see the example of Shenyang in Antoine Kernen, "State Enterprises in Shenyang. Actors and Victims in the Transition", China Perspectives, No. 14, November-December 1997, pp. 26-32.

34.See Kelle S. Tsai, Back-Alley Banking, Private Entrepreneurs in China, Ithaca and London, Cornell University Press, 2002.

35. In this interview, the high level of family borrowing (almost 1 million yuan) can be explained by the high quality of the family network. In particular, the informant had a brother working abroad.

36. In fact, the state banks lent money to one of the three private sock factories, but this seems exceptional (interview).

37. Interview with Mr Wang.

38. Interview with a xiagang.

39. Ibid.

40. Interview.

41. "Study and proposals for the elaboration of a programme and for the development of the specialised market in textile articles in Yiyang", pp. 5-6 
42. The effective upgrading to security standards of buildings erected for one purpose and now used for something else is a widespread challenge in China, where there are so many "converted" buildings.

43. "Guanyu guihua jianshe ... ", p. 7.

44. "Guanyu guihua jianshe ... “, pp. 9-10.

45. Interview.

46. Wang Hangsheng, "Finances publiques et marchés locaux », in Isabelle Thireau, op. cit., 2002, pp. 53-66.

47. Shen Yuan, « Naissance d'un marché », in I. Thireau, op. cit., 2002, pp. 19-36.

48. Research is being conducted into the means of co-operation and competition among private entrepreneurs.

49. I. Thireau, op. cit., 2002, p. 12.

50. Their situation recalls family production workshops in Taiwan in the 1970s (see Hill Gates, "Dependency and Part-time Proletariat in Taiwan", Modern China, Vol. 5, No. 3, July 1979, pp. 381-407), with the major difference that the latter produced for the international market.

INDEX

Thèmes : economie 